\title{
microRNA-192, -194 and -215 are frequently downregulated in colorectal cancer
}

\author{
YEUNPO CHIANG ${ }^{*}$, YONGXI SONG ${ }^{*}$, ZHENNING WANG, ZHUANGKAI LIU, PENG GAO, \\ JIWANG LIANG, JINLIANG ZHU, CHENGZHONG XING and HUIMIAN XU \\ Department of Surgical Oncology and General Surgery, First Hospital \\ of China Medical University, Shenyang 110001, P.R. China
}

Received October 11, 2011; Accepted December 22, 2011

DOI: $10.3892 /$ etm.2011.436

\begin{abstract}
RNAs (miRNAs) are small, non-coding RNAs of endogenous origin. They have been increasingly shown to have aberrant expression in a number of tumor types. miR-192, -194 and -215 have not been comprehensively investigated using a large number of cases in colorectal cancer (CRC). We extracted total RNA from 107 CRC tissues and three CRC cell lines. Following polyadenylation and reverse transcription, the expression levels of miR-192, -194 and -215 were determined for evaluation of the association between expression levels and clinicopathological characteristics by a quantitative real-time polymerase chain reaction (real-time PCR) method. Finally, we studied the impact of miR-194 on cell proliferation in HCT-116 cells by MTT assay. miR-192, -194 and -215 were significantly downregulated in CRC tissues (all $\mathrm{p}<0.001$, paired t-test) and cancer cell lines (all $\mathrm{p}<0.05)$ compared to non-tumor counterparts. Moreover, the expression levels of miR-192, -194 and -215 were demonstrated to be associated with increased tumor sizes $(p=0.027, p=0.018$, and $\mathrm{p}=0.027$, respectively; Mann-Whitney U test). Also, there were marked correlations among these miRNAs in CRC tissues (all $\mathrm{p}<0.001$, Pearson's regression analysis). Furthermore, we found that the overexpression of miR-194 could significantly inhibit cell proliferation in HTC-116 cells. miR-192, -194 and -215 may be important biological markers as tumor suppressors in the carcinogenesis of CRC.
\end{abstract}

\section{Introduction}

microRNAs (miRNAs) are endogenous small single-strand non-coding RNAs of approximately 22 nucleotides (1) that

Correspondence to: Dr Zhenning Wang, Department of Surgical Oncology and General Surgery, First Hospital of China Medical University, Shenyang 110001, P.R. China

E-mail: josieon826@yahoo.com.cn

*Contributed equally

Key words: microRNA, miR-192, miR-194, miR-215, colorectal cancer have emerged as a prominent class of gene regulators. miRNAs may have causal roles in numerous normal cellular and tumor processes, such as development, differentiation, proliferation and apoptosis $(2,3)$. Moreover, a growing number of miRNAs have been classified as oncogenes or tumor-suppressor genes $(4,5)$. Over the past decade, an increasing number of studies have shown dysregulation of miRNA expression in numerous tumor types including esophageal (6), lung (7), liver (8), pancreatic (9), bladder (10), ovarian (11) and gastric cancer (12).

In previous studies, the evidence has revealed that several miRNA expression levels were aberrant in colorectal cancer (CRC). Cummins et al (13) indicated that 53 miRNAs were expressed at significantly different levels between CRC tissues and normal colonic epithelium by microarray and qRT-PCR methods. Moreover, Chen et al (14) indicated that miR-148a and -152 were downregulated, as shown by real-time PCR assay, in a large number of cases with CRC and were significantly related to tumor size and depth of invasion. Our previous study showed similar results, in that miR-203 was significantly downregulated in CRC by real-time PCR assay. Also, the low expression of miR-203 was correlated with increased tumor size and advanced depth of invasion (15). Furthermore, Georges et al (16) reported that miR-192 and -215 were downregulated by microarray and qRT-PCR methods in human CRC cell lines, and these miRNAs, as tumor suppressors, led to cell cycle arrest.

In this study, we detected the expression levels of miR-192, -194 and -215 in a large number of CRC tissues, relative to their non-tumor counterparts, by real-time PCR assay, as well as in three CRC cell lines. Further investigation revealed that aberrant expression of these miRNAs was, notably, correlated with clinicopathological characteristics in CRC. Moreover, we studied the association between miR-194 and cell proliferation in vitro by MTT assay. Our findings will help to elucidate the functions of miRNAs and their role in carcinogenesis.

\section{Material and methods}

Tissues samples. A total of 107 pairs of CRC tissues and nontumor adjacent tissues (NATs; as the controls) were obtained from patients that underwent radical resection between 2007 and 2010 at the First Hospital of China Medical University 
(Shenyang, China). The non-tumor counterparts were obtained from a section of the resected specimen at the farthest distance from the tumor. The samples were snap-frozen in liquid nitrogen immediately following surgery and were stored at $-80^{\circ} \mathrm{C}$ until use. No previous local or systemic treatment had been conducted on these patients prior to surgery.

CRC was subsequently diagnosed based on histopathological evaluation. One section of each sample was stained with hematoxylin-eosin (H\&E). The histological grade of cancer was classified using the TNM staging system of the American Joint Committee on Cancer (AJCC; 2010) and the International Union Against Cancer (UICC), according to the standard of the World Health Organization (WHO). Informed consent was obtained from all patients. The study was approved by the Research Ethics Committee of China Medical University (Shenyang, China).

Cell lines. Human CRC cell lines (HT-29, HCT-116 and SW-620) were obtained from the Institute of Biochemistry and Cell Biology at the Chinese Academy of Sciences (Shanghai, China). HT-29 and HCT-116 were cultured in McCoy's 5A medium (Invitrogen, Carlsbad, CA, USA); SW-620 was cultured in Leibovitz's L-15 medium (Invitrogen). All of the cell lines were cultured at $37^{\circ} \mathrm{C}$ in a humidified atmosphere of $5 \% \mathrm{CO}_{2}$. Media were supplemented with $10 \%$ fetal bovine serum (FBS).

RNA isolation and reverse transcription reaction. Total RNA was isolated from the specimens using a mirVana miRNA Isolation kit (Ambion, Austin, TX, USA) according to the manufacturer's instructions. A UV spectrophotometry NanoPhotometer UV/Vis spectrophotometer (Implen, Schatzbogen, München, Germany) was used to determine the concentration and purity of RNA. A poly(A) tail was added to RNA in a $37^{\circ} \mathrm{C}$ water bath for $30 \mathrm{~min}$ by Escherichia coli poly(A) polymerase (E-PAP) using a Poly(A) Tailing kit, according to the manufacturer's instructions (Ambion) (17). Following purification by phenol-chloroform and ethanol, RNAs were dissolved in diethyl pyrocarbonate (DEPC)-treated water. The first-strand cDNA was synthesized with the SuperScript ${ }^{\circledR}$ III First-Strand Synthesis System using a reverse transcription-polymerase chain reaction kit (Invitrogen). To generate cDNA of miRNA, a $10 \mu 1$ reverse transcription reaction mixture containing $1 \mu \mathrm{g}$ of the RNA sample, $1 \mu$ l RT-primer (Table I), $1 \mu 110 \mathrm{mM}$ deoxyribonucleotide triphosphate (dNTP) mix and DEPC-treated water at $65^{\circ} \mathrm{C}$ was incubated for $5 \mathrm{~min}$. Then, a $10 \mu \mathrm{l}$ mixture containing $2 \mu 1$ 10X RT buffer, $4 \mu 125$ mM MgCl $2,2 \mu 10.1$ M DTT, $1 \mu \mathrm{l}$ RNaseOUT (40 U/ $\mu \mathrm{l})$ and $1 \mu \mathrm{l}$ SuperScript III RT (200 U/ $\mu \mathrm{l})$ was added. The total reaction mixture was incubated in a 96-well plate of a GeneAmp PCR 9700 Thermocycler (Applied Biosystems, Hayward, CA, USA) for $50 \mathrm{~min}$ at $50^{\circ} \mathrm{C}, 5 \mathrm{~min}$ at $85^{\circ} \mathrm{C}$, and $20 \mathrm{~min}$ at $37^{\circ} \mathrm{C}$ after adding $1 \mu \mathrm{l} \mathrm{RNase} \mathrm{H}$ to the mixture, and held at $4^{\circ} \mathrm{C}$.

Real-time PCR. According to the manufacturer's instructions, real-time PCR was performed using the SYBR Premix Ex Taq $^{\text {TM }}$ II kit (Takara Bio, Kyoto, Japan) with a Rotor-gene 6000 system (Qiagen, Valencia, CA, USA) (17). The $25 \mu \mathrm{l}$ mixture of PCR consisted of $12.5 \mu \mathrm{l} \mathrm{SYBR}$ Green supermix, $8.5 \mu \mathrm{l}$
RNase-free water, $1 \mu$ forward primers, $1 \mu$ l reverse primers and $2 \mu \mathrm{l}$ reverse transcribed product. Threshold cycle data were determined by setting a default threshold. The reactive condition was 45 amplification cycles of $95^{\circ} \mathrm{C}$ for $5 \mathrm{sec}, 58^{\circ} \mathrm{C}$ for $20 \mathrm{sec}$ and $72^{\circ} \mathrm{C}$ for $30 \mathrm{sec}$ in a 36 -well optical plate using a Rotor-gene 6000 system. The U6 RNA was selected as an endogenous reference to calculate the relative expression levels of miR-192, -194 and -215 in cancerous samples compared to non-tumor counterparts using the $2^{-\Delta \Delta \mathrm{Ct}}$ method (18). All samples were performed in triplicate and repeated three times. The products of real-time PCR were confirmed by TA cloning and a sequencing assay. The primers for miR-192, -194 and -215 and the endogenous control U6 are shown in Table I.

Cell transfection and MTT assay. miR-194 mimics were composed of an RNA duplex (Table I) designed as described previously (19). Non-specific sequences were non-homologous to any human genome sequences as a negative control RNA duplex (named as NC, Table I). Corresponding 2-O-methyl analogues were used to substitute for all pyrimidine nucleotides in the miR-194 mimics or NC to improve RNA stability for an MTT assay in vitro. miR-194 mimics (50 nM) and NC were transiently transfected in cultured SGC-7901 cells at 30-50\% confluence using Lipofectamine 2000 (Invitrogen). All the RNA oligoribonucleotides were chemically synthesized by GenePharma (Shanghai, China).

The 3-(4,5-dimethylthiazol-2-yl)-2,5-diphenyltetrazolium bromide (MTT) assay was performed to measure the capacity for cellular proliferation. A total of $24 \mathrm{~h}$ following transfection, cells (approximately $0.4 \times 10^{4}$ ) were seeded into 96-well microtiter plates for 24, 48, 72 and $96 \mathrm{~h}$. Then, the cells were incubated with $20 \mu \mathrm{l}$ of MTT $(5 \mathrm{mg} / \mathrm{ml})$ for $4 \mathrm{~h}$ at $37^{\circ} \mathrm{C}$ and $150 \mu \mathrm{l}$ of dimethyl sulfoxide (DMSO) was added to solubilize the crystals for $20 \mathrm{~min}$ at room temperature. A spectrophotometer (Multiskan MK3; Thermo, Waltham, MA, USA) was used to measure the optical density (OD) at a wavelength of $490 \mathrm{~nm}$. All experiments were performed three times to calculate the average results. The growth inhibition rate was calculated as follows: $(\mathrm{AC}-\mathrm{AT}) / \mathrm{AC} \times 100 \%$ (AC = absorbance value of the $\mathrm{NC} ; \mathrm{AT}=$ absorbance value of the experimental group) (20).

Statistical analysis. For real-time PCR, the threshold cycle of fluorescence $\left(C_{t}\right)$ for each sample was determined to evaluate the association between CRC tissues and matched NATs by the $2^{-\Delta \Delta \mathrm{Ct}}$ method. $\Delta \Delta \mathrm{C}_{\mathrm{t}}$ indicates the difference in the $\Delta \mathrm{C}_{\mathrm{t}}$ value between cancer tissue and the corresponding control $\left(\Delta \Delta \mathrm{C}_{\mathrm{t}}=\right.$ $\left.\Delta \mathrm{C}_{\mathrm{t} \text { cancer }}-\Delta \mathrm{C}_{\mathrm{t} \text { control }}\right)$ and $\Delta \mathrm{C}_{\mathrm{t}}$ is the difference of the $\mathrm{C}_{\mathrm{t}}$ value between the target and $\mathrm{U} 6\left(\Delta \mathrm{C}_{\mathrm{t}}=\mathrm{C}_{\mathrm{t} \text { target }}-\mathrm{C}_{\mathrm{tU}}\right)$. Finally, the $2^{-\Delta \Delta \mathrm{Ct}}$ value (fold value) was calculated and distinguished as 1-fold, and a fold value of less than 1-fold was defined as low expression $(15,21)$. Differences in miRNA expression were measured by comparing the values of $\Delta C_{t}$ cancer and $\Delta C_{t}$ control, and statistical differences in miRNA expression levels were determined using a paired t-test in cancer tissues and cancer cell lines relative to non-tumor counterparts, as well as comparing the effect of miR-194 on cell proliferation in HCT-116 cells by MTT assay. Moreover, the association between miRNA expression levels and clinicopathological parameters was analyzed by a non-parametric test (Mann-Whitney U test between two groups and Kruskal-Wallis $\mathrm{H}$ test for three or 
Table I. RT-PCR primers for amplification of miR-192, -194 and -215 expression and the sequences of miR-194 mimics and NC.

\begin{tabular}{ll}
\hline Primer & \multicolumn{1}{c}{ Primer sequence $\left(5^{\prime}-3^{\prime}\right)$} \\
\hline RT-primer-1 & GCTGTCAACGATACGCTACGTAACGGCATGACAGTGTTTTTTTTTTTTTTTTTTTTTTTTA \\
RT-primer-2 & GCTGTCAACGATACGCTACGTAACGGCATGACAGTGTTTTTTTTTTTTTTTTTTTTG \\
RT-primer-3 & GCTGTCAACGATACGCTACGTAACGGCATGACAGTGTTTTTTTTTTTTTTTTTTTTTC \\
miR-192-F & CTGACCTATGAATTGACAGCCA \\
miR-192-R & GCTGTCAACGATACGCTACGT \\
miR-194-F & TGTAACAGCAACTCCATGTGGA \\
miR-194-R & GCTGTCAACGATACGCTACGT \\
miR-215-F & ATGACCTATGAATTGACAGACAA \\
miR-215-R & GCTGTCAACGATACGCTACGT \\
U6 RNA-F & CGCTTCGGCAGCACATATAC \\
U6 RNA-R & TTCACGAATTTGCGTGTCAT \\
miR-194-mimics & UGUAACAGCAACUCCAUGUGGA \\
& CACAUGGAGUUGCUGUUACAUU \\
NC & UUCUUCGAACGUGUCACGUTT \\
& ACGUGACACGUUCGGAGAATT
\end{tabular}

${ }^{a}$ Forward primer. ${ }^{b}$ Reverse primer. NC, negative control RNA duplex.

more groups). $\mathrm{P}<0.05$ was considered to indicate a statistically significant difference. Statistical analyses were performed using the Statistical Program for Social Sciences (SPSS) software 16.0 (SPSS Incorporated, Chicago, IL, USA).

\section{Results}

Expression of miR-192, -194 and -215 in CRC. Among 107 patients with CRC, expression levels of miR-192, -194 and -215 were detected using real-time PCR in cancer tissues compared to matched non-tumor counterparts and the values of $\Delta \mathrm{C}_{\mathrm{t}}$ (means $\pm \mathrm{SD}$ ) were $4.632 \pm 2.090,4.680 \pm 2.170$ and $6.483 \pm 2.242$ in cancer tissues, and $2.207 \pm 2.704,2.780 \pm 2.922$ and $4.032 \pm 2.768$ in non-tumor counterparts, respectively. Moreover, miR-192, -194 and -215 were significantly downregulated in CRC tissues with the median 0.13-fold, 0.23-fold, and 0.15 -fold relative to the control group, respectively (all $\mathrm{p}<0.001$, paired t-test; Fig. 1). Furthermore, in 87 of 107 (81.30\%), 85 of 107 (79.44\%) and 86 of 107 (80.37\%) cases, miR-192,-194 and -215 expression levels revealed a $>50 \%$ reduction between the two types of tissues. In the cell lines, we also found a significantly lower expression of miR-192, -194 and -215 in HT-29 cells $(p=0.003, p=0.016$, and $p=0.002$, respectively; paired t-test), HCT-116 cells ( $\mathrm{p}=0.003, \mathrm{p}=0.014$ and $\mathrm{p}=0.001$, respectively) and SW-620 cells $(\mathrm{p}=0.002, \mathrm{p}=0.010$ and $\mathrm{p}=0.002$, respectively) compared to normal colorectal tissues (Fig. 2).

Association between expression of miRNAs and clinicopathological characteristics in CRC. In our study, there was an association between miRNA expression levels and clinicopathological characteristics in CRC. Lower expression levels of miR-192, -194 and -215 in patients with CRC tended to be associated with increased tumor sizes as shown by nonparametric tests $(p=0.027, p=0.018$ and $p=0.027$, respectively; Mann-Whitney U test, Table II). There was no significant difference between low expression of the miRNAs and other clinicopathological characteristics such as gender, age, histological grade, $\mathrm{pT}$ stage, $\mathrm{pN}$ stage, clinical stage, lymph node metastasis rate and lymphatic vessel invasion.

Marked correlations among miR-192, -194 and -215. There were marked correlations between miR-192 and -194, miR-192 and -215, and miR-194 and -215 in CRC tissues, which were evaluated by Pearson's regression analysis (all p<0.001; Fig. 3). The correlation coefficients were $0.950,0.895$, and 0.856 , respectively.

Effects of miR-194 on cell proliferation. The effect of miR-194 on cell proliferation was assessed in HCT-116 cells. The transfection efficiency was detected by the real-time PCR method $48 \mathrm{~h}$ following transfection. Moreover, we found that the cells that were transfected with miR-194 mimics in HCT-116 cells had marked growth inhibition at the point of $96 \mathrm{~h}$ post-transfection compared to the matched NC and SCG-7901 cells, as shown by the MTT assay (Fig. 4). Furthermore, the inhibition rate was $19.20 \%$ at the point of $96 \mathrm{~h}$ post-transfection in HCT-116 cells.

\section{Discussion}

In recent years, studies have shown that miRNA alterations may function as a novel class of oncogenes and tumor suppressors, which could be used for the diagnosis and treatment of cancer (22). Mathé et al (6) reported that miR-192 and -194 were upregulated in 107 patients with esophageal cancer compared to non-tumor counterparts by microarray assay. Moreover, Jin et al (23) indicated that miR-192 and -215 in gastric cancer tissues and cell lines were upregulated by microarray and qRT-PCR methods. Furthermore, more evidence revealed the upregulated miR-192 in lung cancer, 
A

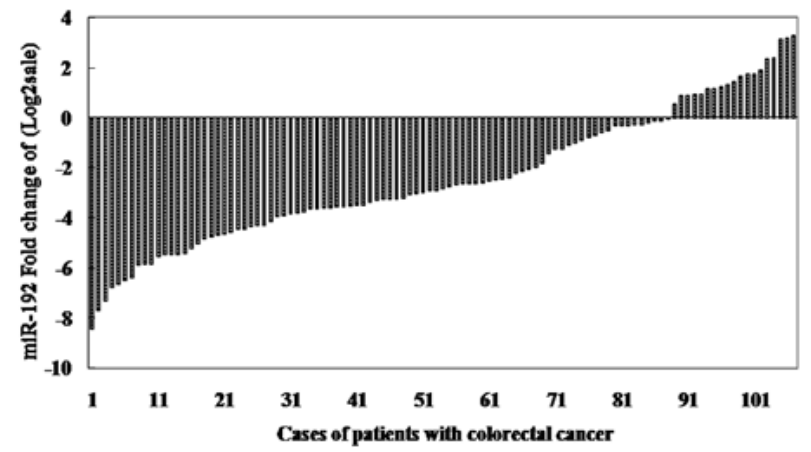

C

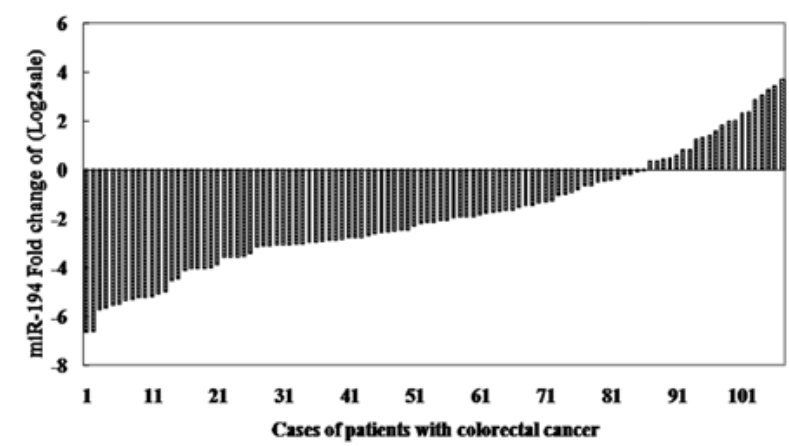

E

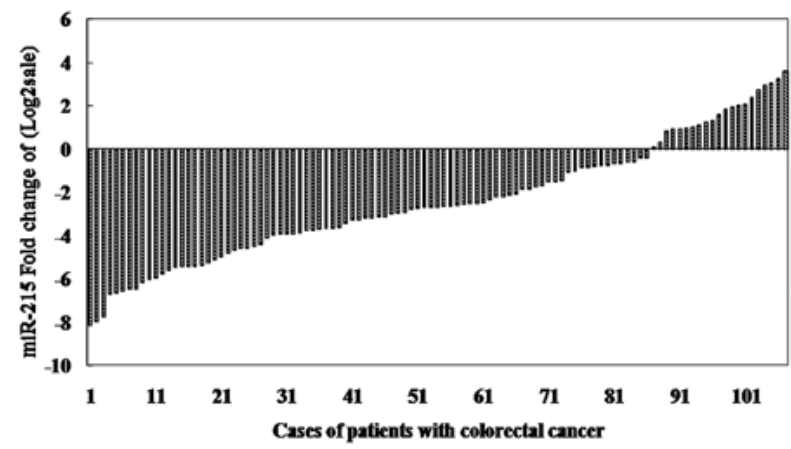

B

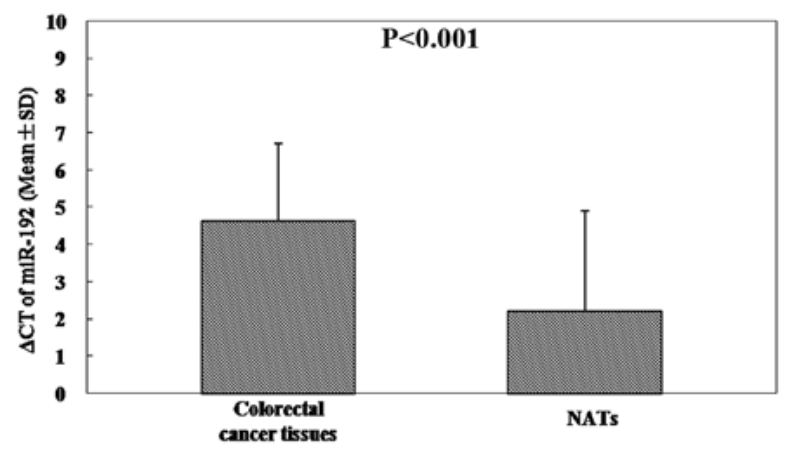

D

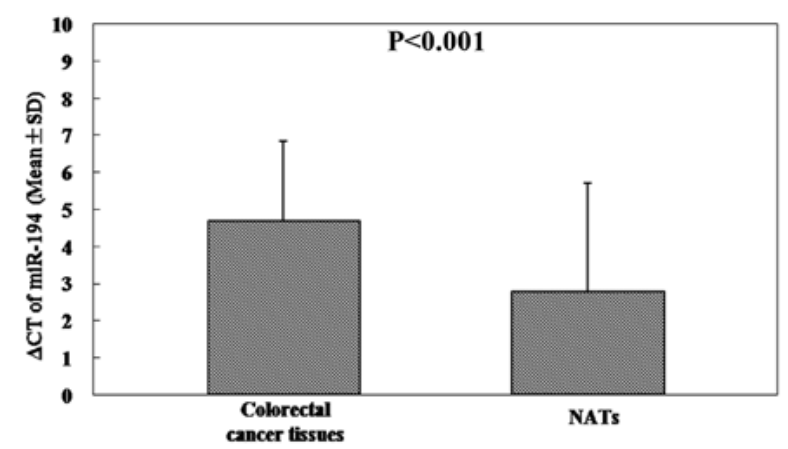

F

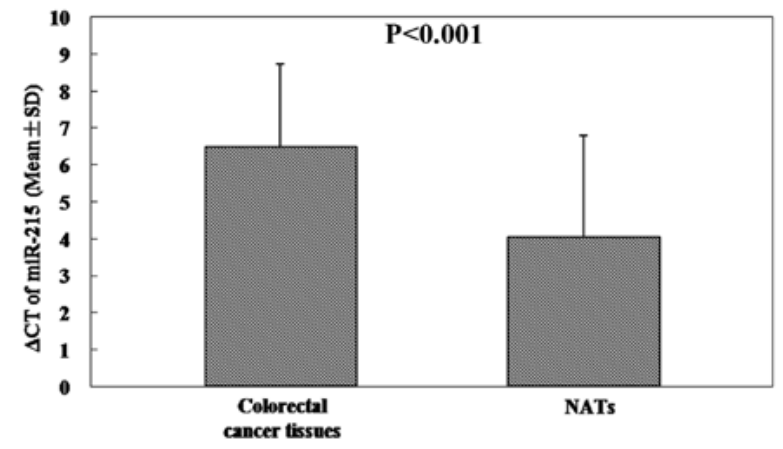

Figure 1. Expression levels of miR-192,-194 and -215 in 107 patients with colorectal cancer (CRC). (A, C and E) Quantification of miRNAs was measured by SYBR Premix Ex Taq II. Each sample was analyzed in triplicate and repeated three times. Data are presented as log2 of fold-change of CRC tissues relative to matched NATs. (B, D and F) miR-192, -194 and -215 were differentially expressed between CRC tissues and NATs. These miRNAs were normalized by U6RNA. $\Delta \mathrm{C}_{\mathrm{t}}=\mathrm{C}_{\mathrm{t} \text { miRnAs }}-\mathrm{C}_{\mathrm{t} \text { U6RNA }}$. The $\Delta \mathrm{C}_{\mathrm{t}}$ of these miRNAs was significantly higher in CRC tissues than NATs (p<0.001, paired t-test). NATS, non-tumor adjacent tissues.

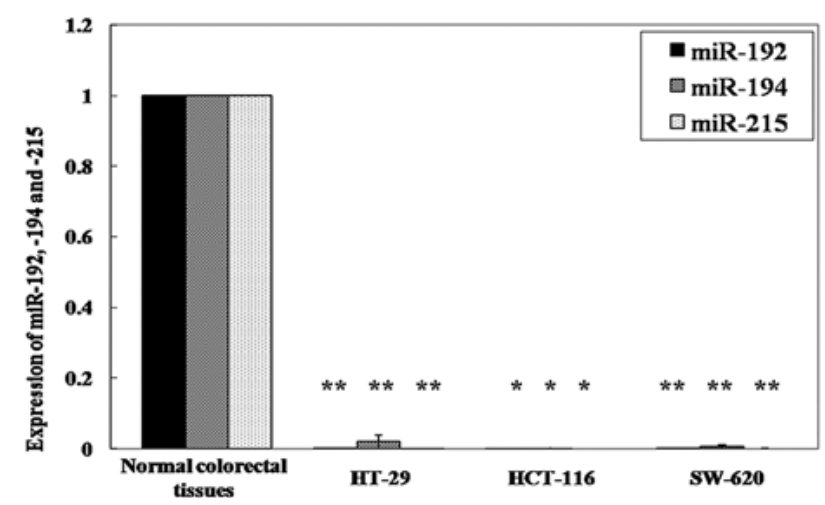

Figure 2. Expression levels of miR-192, -194 and -215 in three colorectal cancer (CRC) cell lines (HT-29, HCT-116 and SW-620). Quantification of miRNAs was measured by SYBR Premix Ex Taq II. Data are presented in CRC cell lines relative to normal colorectal tissues (randomly selected 3 NATs from previous 107 cases of CRC as controls, $\left.{ }^{*} \mathrm{p}<0.05,{ }^{* *} \mathrm{p}<0.01\right)$. NATS, non-tumor adjacent tissues. overexpression of miR-194 in highly metastatic pancreatic ductal adenocarcinoma, and overexpression of miR-215 in hepatocellular carcinoma by microarray and real-time PCR methods (7-9). However, miR-194 in mouse hepatocellular carcinoma and cancer cell lines was downregulated by the real-time PCR method (24). Therefore, the altered miRNA expression levels may cause tissue-specific differences. Just as Baffa et al suggested, the various miRNA expression levels, which were observed in different organs of origin, were markedly tissue-specific (25). In the future, the correlation between miRNAs and cancer could become a focus of cancer studies.

miRNAs can be quantified by microarray assay, bead-based flow cytometric assay and real-time PCR assay. The main advantage of real-time PCR is that it is more quantitative and sensitive than other assays. Therefore, we performed real-time PCR on a large number of cases to assess the expression levels of miR-192, -194 and -215 in CRC. The significantly lower 
Table II. Association between miR-192,-194 and -215 expression and clinicopathological features in patients with colorectal cancer.

\begin{tabular}{|c|c|c|c|c|}
\hline Colorectal cancer & $\mathrm{n}$ & $\operatorname{miR}-192^{\mathrm{a}}$ & $\operatorname{miR}-194^{\mathrm{a}}$ & $\operatorname{miR}-215^{\mathrm{a}}$ \\
\hline \multicolumn{5}{|l|}{ Gender } \\
\hline Male & 64 & $0.121(0.047-0.748)$ & $0.193(0.085-0.727)$ & $0.151(0.041-0.586)$ \\
\hline Female & 43 & $0.189(0.069-0.909)$ & $0.265(0.118-1.257)$ & $0.195(0.066-0.623)$ \\
\hline p-value & & 0.360 & 0.225 & 0.382 \\
\hline \multicolumn{5}{|l|}{ Age (years) } \\
\hline$<65$ & 59 & $0.159(0.073-0.825)$ & $0.234(0.118-0.772)$ & $0.177(0.074-0.578)$ \\
\hline$\geq 65$ & 48 & $0.111(0.047-0.797)$ & $0.227(0.085-0.727)$ & $0.116(0.032-0.622)$ \\
\hline P-value & & 0.208 & 0.507 & 0.146 \\
\hline \multicolumn{5}{|l|}{ Tumor size (cm) } \\
\hline$<5$ & 46 & $0.221(0.079-1.849)$ & $0.331(0.127-1.562)$ & $0.205(0.077-1.793)$ \\
\hline$\geq 5$ & 61 & $0.106(0.039-0.416)$ & $0.174(0.064-0.452)$ & $0.112(0.034-0.557)$ \\
\hline p-value & & $0.027^{\mathrm{b}}$ & $0.018^{\mathrm{b}}$ & $0.027^{\mathrm{b}}$ \\
\hline \multicolumn{5}{|l|}{ Tumor location } \\
\hline Colon & 48 & $0.114(0.041-0.764)$ & $0.176(0.062-0.703)$ & $0.113(0.031-0.647)$ \\
\hline Rectum & 59 & $0.142(0.074-0.809)$ & $0.261(0.123-0.875)$ & $0.165(0.074-0.578)$ \\
\hline p-value & & 0.301 & 0.158 & 0.250 \\
\hline \multicolumn{5}{|l|}{ Histological grade } \\
\hline Well/moderately well differentiated & 84 & $0.132(0.053-0.855)$ & $0.231(0.115-0.972)$ & $0.153(0.048-0.654)$ \\
\hline Poorly differentiated & 23 & $0.159(0.051-0.492)$ & $0.227(0.067-0.489)$ & $0.174(0.047-0.557)$ \\
\hline p-value & & 0.562 & 0.363 & 0.985 \\
\hline \multicolumn{5}{|l|}{ pT stage } \\
\hline $\mathrm{T} 2+\mathrm{T} 3$ & 80 & $0.155(0.065-0.809)$ & $0.258(0.118-0.848)$ & $0.163(0.064-0.639)$ \\
\hline $\mathrm{T} 4$ & 27 & $0.106(0.023-0.614)$ & $0.204(0.028-0.735)$ & $0.113(0.023-0.618)$ \\
\hline p-value & & 0.168 & 0.181 & 0.213 \\
\hline \multicolumn{5}{|l|}{ pN stage } \\
\hline N0 & 67 & $0.142(0.057-0.809)$ & $0.227(0.115-0.735)$ & $0.154(0.058-0.664)$ \\
\hline $\mathrm{N} 1$ & 30 & $0.132(0.036-0.794)$ & $0.248(0.059-0.798)$ & $0.150(0.040-0.565)$ \\
\hline $\mathrm{N} 2$ & 10 & $0.159(0.061-0.912)$ & $0.222(0.105-1.282)$ & $0.135(0.046-0.958)$ \\
\hline p-value & & 0.836 & 0.884 & 0.936 \\
\hline \multicolumn{5}{|l|}{ pTNM stage } \\
\hline $\mathrm{I}+\mathrm{II}$ & 67 & $0.142(0.057-0.809)$ & $0.227(0.115-0.735)$ & $0.154(0.058-0.664)$ \\
\hline III & 40 & $0.132(0.051-0.797)$ & $0.248(0.073-0.849)$ & $0.150(0.043-0.581)$ \\
\hline p-value & & 0.718 & 0.779 & 0.804 \\
\hline \multicolumn{5}{|l|}{ Invasion into lymphatic vessels } \\
\hline Negative & 97 & $0.131(0.054-0.796)$ & $0.227(0.114-0.741)$ & $0.154(0.051-0.604)$ \\
\hline Positive & 10 & $0.203(0.048-1.612)$ & $0.227(0.084-1.317)$ & $0.218(0.044-1.090)$ \\
\hline p-value & & 0.604 & 0.957 & 0.696 \\
\hline
\end{tabular}

${ }^{a}$ Median of relative expression with 25 th- 75 th percentile is recorded in parentheses. ${ }^{b} \mathrm{p}<0.05$.

expression of these miRNAs was found in 107 cancer tissues compared to non-tumor counterparts. Moreover, research on the miRNA expression levels in CRC cell lines also provided similar significant results. In previous studies, similar results indicated that miR-192, -194 and -215 were downregulated in CRC cell lines and rat colon tissues $(16,26,27)$. Furthermore, our studies revealed that the increased tumor size in CRC was closely correlated with the low expression of miR-192, -194 and -215 . There was also an inverse correlation between tumor size and miRNA expression levels, with lower expression levels being associated with increased tumor size. Although the increased tumor size in CRC was not part of the staging system, previous studies have suggested that tumor size is also an important prognostic factor in CRC (28). Thus, miR-192, -194 and -215 might be important biological markers in the carcinogenesis of CRC and the low expression of these miRNAs may contribute to the proliferation of CRC.

In the present study, we found a marked correlation between miR-192 and -194, miR-192 and -215, and miR-194 and -215 in CRC tissues. As shown on the miRBase and HGNC website, 
A

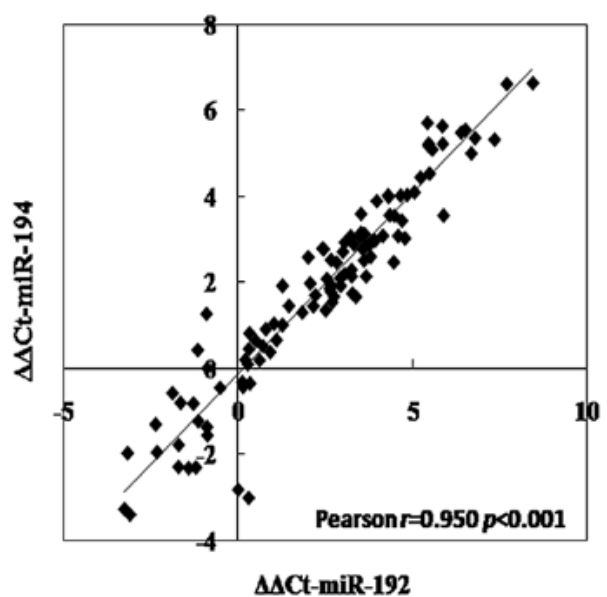

B

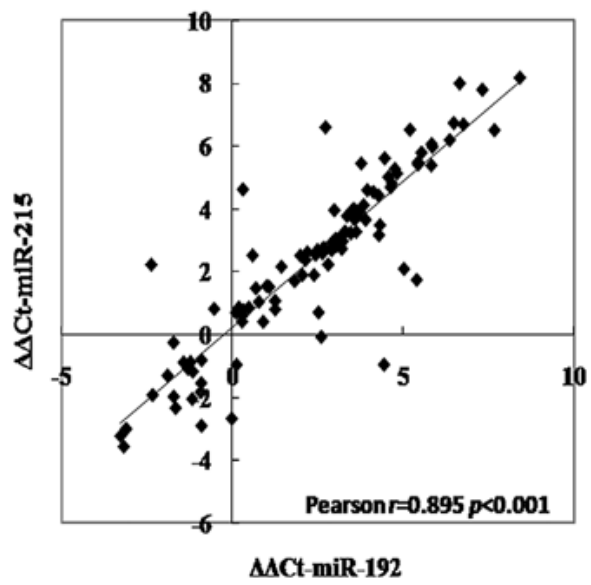

C

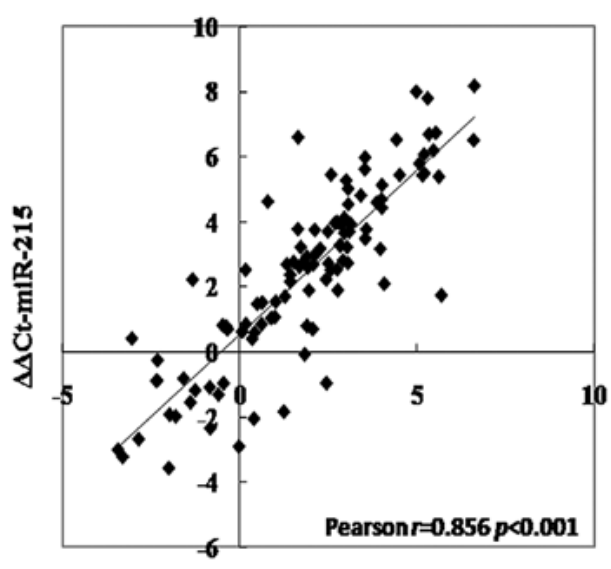

AMCt-miR-194

Figure 3. The marked correlation between miR-192 and -194, miR-192 and -215, and miR-194 and -215 in colorectal cancer tissues. $\Delta \Delta \mathrm{C}_{\mathrm{t}-\mathrm{miRNA}}=\left(\mathrm{C}_{\mathrm{t} \text {-tumor- }}\right.$ miRNA $\left.-\mathrm{Ct}_{\text {tumor-U6RNA }}\right)-\left(\mathrm{C}_{\mathrm{t} \text {-non-tumor-iRNA }}-\mathrm{C}_{\mathrm{t} \text {-non-tumor-U6RNA }}\right)$. (A) Correlation in the $\Delta \Delta \mathrm{C}_{\mathrm{t}}$ value between miR-192 and -194. (B) Correlation in the $\Delta \Delta \mathrm{C}_{\mathrm{t}}$ value between miR-192 and -215. (C) Correlation in the $\Delta \Delta C_{t}$ value between miR194 and -215 .

miR-192 and -215 have the same 'seed region'; miR-192 and -194-2 are on the same chromosome at the 11q13.1 and miR-194-1 and -215 are on 1q41. Moreover, the mature sequence of miR-194-1 and -194-2 is miR-194. We therefore suggest that miRNAs may contribute to the carcinogenesis of CRC in synergism. Confirmation of this theory requires further investigation.

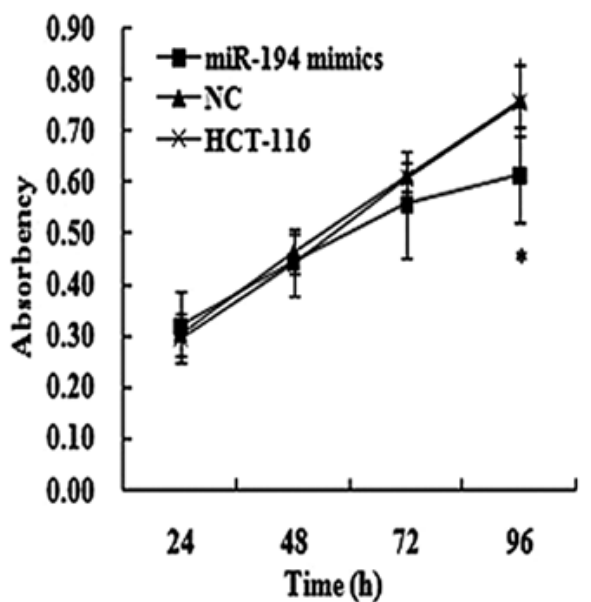

Figure 4. miR-194 significantly inhibited cell proliferation in HCT-116 cells by MTT assay $\left({ }^{*} \mathrm{P}<0.05\right)$.

In a previous study, Boni et al indicated that miR-192 and -215 in DLD-1 CRC cell lines induced the accumulation of p53 and suppressed cell proliferation in a partially, but not completely, p53-dependent pathway (29). Furthermore, Song et al also found similar results in HCT-116 CRC cell lines transfected with miR-215. Their results suggest that the reduced proliferation rate is due to a decreased $\mathrm{S}$ phase and increased G2 checkpoint control (30). More evidence was observed that miR-192 and -215 may function as tumor suppressors capable of inhibiting cell proliferation, suppressing carcinogenesis through p21 accumulation, and causing cell cycle arrest in CRC cell lines $(16,26,31)$. In the present study, cell proliferation assays were performed in HTC-116 cells to investigate the potential impact of miR-194 on cell growth. Our results showed that miR-194 mimics transfection in HCT-116 cells was significantly lower than the NC group and blank group by MTT assay. Thus, we suggest that the overexpression of miR-194 may be a potential biological marker for the inhibition of cell proliferation in CRC. Future studies on the functions of these miRNAs are required to further the investigation of CRC.

There are a number of factors that may reduce miRNA expression, including transcriptional factors, mutations, deletions and methylation. Recent studies have shown that hypermethylation of the miR-194-2 and -192 cluster promoter in multiple myeloma (MM) cell lines suggests that epigenetic downregulation of these miRNAs, which leads to an increase in murine double minute 2 (MDM2) mRNA and protein expression, decreases the ability of p53 to downmodulate MDM2 expression (32). Moreover, Hino et al (33) indicated that miR-194 was transcriptionally upregulated in a gastrointestinal tract enriched nuclear receptor by the hepatic nuclear factor $1 \alpha$ (HNF1- $\alpha)$ in intestinal epithelial cells. Therefore, considering these reasons, we speculate that hypermethylation and transcription factors may be mechanisms for the downregulation of miR-192, -194 and -215 in CRC.

In a large number of CRC tissues, miR-192, -194 and -215 were significantly downregulated relative to their non-tumor counterparts, as well as in the three CRC cell lines. Also, a significant association between these miRNA expression levels and increased tumor size was found in CRC. Moreover, 
there was a marked correlation among these miRNAs in CRC tissues. An in vitro cell proliferation assay revealed that the miR-194 mimics transfection in HCT-116 cells was significantly lower than controls. The present study indicates a basis for further studies on target genes and identification of more functions of these miRNAs in CRC. In future studies, the associations between these miRNAs and the prognosis of patients with CRC need to be confirmed using large-scale and long-term follow-up studies.

\section{Acknowledgements}

This study was supported by grants from the National Science Foundation of China (No. 30972879 and No. 81000943), Specialized Research Fund for the Doctoral Program of Higher Education (No. 200801590006) and Natural Science Foundation of Liaoning Province (No. 20092129).

\section{References}

1. Bartel DP: MicroRNAs: genomics, biogenesis, mechanism, and function. Cell 116: 281-297, 2004.

2. Calin GA and Croce CM: MicroRNA-cancer connection: the beginning of a new tale. Cancer Res 66: 7390-7394, 2006.

3. Li M, Li J, Ding X, He M and Cheng SY: microRNA and cancer. AAPS J 12: 309-317, 2010.

4. Cho WC: OncomiRs: the discovery and progress of microRNAs in cancers. Mol Cancer 6: 60, 2007.

5. Calin GA and Croce CM: MicroRNA signatures in human cancer. Nat Rev Cancer 6: 857-866, 2006.

6. Mathé EA, Nguyen GH, Bowman ED, et al: MicroRNA expression in squamous cell carcinoma and adenocarcinoma of the esophagus: associations with survival. Clin Cancer Res 15 : 6192-6200, 2009.

7. Yanaihara N, Caplen N, Bowman E, et al: Unique microRNA molecular profiles in lung cancer diagnosis and prognosis. Cancer Cell 9: 189-198, 2006.

8. Gui J, Tian Y, Wen X, et al: Serum microRNA characterization identifies miR-885-5p as a potential marker for detecting liver pathologies. Clin Sci 120: 183-193, 2011.

9. Mees ST, Mardin WA, Wendel C, et al: EP300 - a miRNAregulated metastasis suppressor gene in ductal adenocarcinomas of the pancreas. Int J Cancer 126: 114-124, 2010.

10. Gottardo F, Liu CG, Ferracin M, et al: Micro-RNA profiling in kidney and bladder cancers. Urol Oncol 25: 387-392, 2007.

11. Iorio MV, Visone R, Di Leva G, et al: MicroRNA signatures in human ovarian cancer. Cancer Res 67: 8699-8707, 2007.

12. Song YX, Yue ZY, Wang ZN, et al: MicroRNA-148b is frequently down-regulated in gastric cancer and acts as a tumor suppressor by inhibiting cell proliferation. Mol Cancer 10: 1, 2011.

13. Cummins JM, He Y, Leary RJ, et al: The colorectal microRNAome. Proc Natl Acad Sci USA 103: 3687-3692, 2006.

14. Chen Y, Song Y, Wang Z, Yue Z, Xu H, Xing C and Liu Z: Altered expression of miR-148a and miR-152 in gastrointestinal cancers and its clinical significance. J Gastrointest Surg 14: 1170-1179, 2010.
15. Chiang Y, Song Y, Wang Z, et al: Aberrant expression of miR-203 and its clinical significance in gastric and colorectal cancers. J Gastrointest Surg 15: 63-67, 2011.

16. Georges SA, Biery MC, Kim SY, et al: Coordinated regulation of cell cycle transcripts by p53-Inducible microRNAs, miR-192 and miR-215. Cancer Res 68: 10105-10112, 2008.

17. Shi R and Chiang VL: Facile means for quantifying microRNA expression by real-time PCR. Biotechniques 39: 519-525, 2005.

18. Livak KJ and Schmittgen TD: Analysis of relative gene expression data using real-time quantitative pcr and the 2 (delta delta c(T)) method. Methods 25: 402-408, 2001.

19. Lim LP, Lau NC, Garrett-Engele P, et al: Microarray analysis shows that some microRNAs downregulate large numbers of target mRNAs. Nature 433: 769-773, 2005.

20. Luan S, Sun L and Huang F: MicroRNA-34a: a novel tumor suppressor in p53-mutant glioma cell line U251. Arch Med Res 41: 67-74, 2010.

21. Wang CJ, Zhou ZG, Wang L, et al: Clinicopathological significance of microRNA-31, -143 and -145 expression in colorectal cancer. Dis Markers 26: 27-34, 2009.

22. Esquela-Kerscher A and Slack FJ: Oncomirs - microRNAs with a role in cancer. Nat Rev Cancer 6: 259-269, 2006.

23. Jin Z, Selaru FM, Cheng Y, et al: MicroRNA-192 and -215 are upregulated in human gastric cancer in vivo and suppress ALCAM expression in vitro. Oncogene 30: 1577-1585, 2011.

24. Meng Z, Fu X, Chen X, et al: miR-194 is a marker of hepatic epithelial cells and suppresses metastasis of liver cancer cells in mice. Hepatology 52: 2148-2157, 2010.

25. Baffa R, Fassan M, Volinia S, et al: MicroRNA expression profiling of human metastatic cancers identifies cancer gene targets. J Pathol 219: 214-221, 2009.

26. Braun CJ, Zhang X, Savelyeva I, et al: p53-Responsive micrornas 192 and 215 are capable of inducing cell cycle arrest. Cancer Res 68: 10094-10104, 2008.

27. Davidson LA, Wang N, Shah MS, Lupton JR, Ivanov I and Chapkin RS: n-3 Polyunsaturated fatty acids modulate carcinogen-directed non-coding microRNA signatures in rat colon. Carcinogenesis 30: 2077-2084, 2009.

28. Hamilton SR and Aaltonen LA: Pathology and genetics of tumours of the digestive system. In: World Health Organization Classification of Tumours. Kleihuesv P and Sobin LH (eds). IARC Press, Lyon, pp103-144, 2000.

29. Boni V, Bitarte N, Cristobal I, et al: miR-192/miR-215 influence 5-fluorouracil resistance through cell cycle-mediated mechanisms complementary to its post-transcriptional thymidilate synthase regulation. Mol Cancer Ther 9: 2265-2275, 2010.

30. Song B, Wang Y, Titmus MA, Botchkina G, Formentini A, Kornmann $\mathrm{M}$ and $\mathrm{Ju} \mathrm{J}$ : Molecular mechanism of chemoresistance by miR-215 in osteosarcoma and colon cancer cells. Mol Cancer 9: 96, 2010.

31. Song B, Wang Y, Kudo K, Gavin EJ, Xi Y and Ju J: miR-192 Regulates dihydrofolate reductase and cellular proliferation through the p53-microRNA circuit. Clin Cancer Res 14: 8080-8086, 2008.

32. Pichiorri F, Suh SS, Rocci A, et al: Downregulation of p53-inducible microRNAs 192, 194, and 215 impairs the p53/ MDM2 autoregulatory loop in multiple myeloma development. Cancer Cell 18: 367-381, 2010.

33. Hino K, Tsuchiya K, Fukao T, Kiga K, Okamoto R, Kanai T and Watanabe M: Inducible expression of microRNA-194 is regulated by HNF-1alpha during intestinal epithelial cell differentiation. RNA 14: 1433-1442, 2008. 